\title{
The Effect of Soda Pulping Variables on Coir Fiber's Pulp Properties
}

\author{
Maria Ulfa* and Koriatul Isnaini
}

* Department of Chemistry, Faculty of Mathematics and Natural Science

University of Mataram, J1. Majapahit No. 62 Mataram, Nusa Tenggara Barat 83125, Indonesia

E-mail: ulfaarief@unram.ac.id

DOI: $10.29303 /$ aca.v3i2.47

\author{
Article info: \\ Received 31/08/2020 \\ Revised 21/09/2020 \\ Accepted 21/09/2020 \\ Available online 18/10/2020
}

\author{
Abbreviations: \\ SEM: Scanning Electron \\ Microscopy
}

Abstract: The potential use of coir fiber for pulping and papermaking has been investigated. This research aimed to study the effects of pulping processing variables (temperature, pulping time, and alkali charge/solvent pulping) on pulp properties (residual lignin, alpha-cellulose, kappa number, and pulp yield) from coir fiber. For this purpose, the coir fibers were cooked using alkali charge (10 to $20 \%$ oven-dried, as $\mathrm{NaOH})$, pulping time from 60 to $120 \mathrm{~min}$, and temperature from 65 to $180^{\circ} \mathrm{C}$. Results indicated that alkali charge and pulping time had more impact on the properties of pulp than temperature. Pulping at high temperature, long pulping time, and high alkali charge decreased lignin, pulp yield, and kappa number instead of alpha-cellulose content.

Keywords: coir, lignin, soda pulping

Citation: $\quad$ Ulfa, M. \& Isnaini, K. (2020). The effect of soda pulping variables on coir fiber's pulp properties. Acta Chimica Asiana, 3(2), 170-173. DOI: 10.29303/aca.v3i2.47

\section{INTRODUCTION}

Nowadays, non-wood fibers are widely used as raw materials for pulp and papermaking. Initially, non-wood fibers were used to save and preserve forest and ground waste utilization. However, nonwood utilization reasons shifted to the shorter pulping process, fewer chemicals, and pulp properties, almost like the pulp of wood [1] [2]. Many studies have been carried out over many years to investigate the use of agricultural wastes and annual plants such as rice straw, kapok, bamboo, pineapple crown leaves, kenaf, and bagasse [3] [4] [5] as an alternative source of fibers. Generally, the characterization of these fiber sources based on research shows that they can be used as a promising material

In Indonesia, the coconut husk is a byproduct of the large volumes that use limited to domestic industries such as mats and the rest just thrown away or burned. The ability to extract coir fiber from coconut's outer shell has led to its broader application as reinforced composites. Utilization of coir fiber as raw material for pulp and paper is possible because the fiber properties are similar to wood fibers [6] [7] [8] [9] [10]. However, the high content of lignin in fiber and non-fiber (pith) could not be entirely separated from the fiber is a problem in the pulping process. According to [7] and [11], soda pulping is the most effective pulping process that decreases lignin content. The present work is a logical continuation of the previous investigation, intending to study a coir pulp's behavior during an initial delignification phase and pulp properties. First, the impact of processing variables (temperature, pulping time, and alkali charge) on pulp properties (residual lignin, alpha-cellulose, kappa number, and pulp yield) was studied. Then, SEM studies were performed to corroborate the data obtained.

\section{MATERIALS AND METHODS}

\section{Materials and Devices}

Coconut husks were collected from the region of Yogyakarta-Indonesia and defibrated by a defibrator machine to produce coir fibers; Analytical grade sodium hydroxide $(\mathrm{NaOH})$ was purchased from Sigma-Aldrich.

The pulping was carried out in a rotary digester having four bombs, each of $3 \mathrm{~L}$ capacity. Then, the pulps were disintegrated in a mechanical standard disintegrator (Model MK IIIC, Messmer Instruments Ltd) for 75,000 revolutions then stored as stock pulp. Meanwhile, the morphology of pulp is examined by a Phenom electron microscope. 


\section{Methods}

\section{Pretreatment of the raw material}

Before pulping, the coir fiber was cleaned then thoroughly wetted by soaking in water for about 48 hours to remove extraneous dirt, sand, foreign materials and eliminate lignin and pith content. The fibers were dried under natural conditions and then cut into small size fraction with a length of 5 to 6 $\mathrm{cm}$, then stored in polyethylene bags under dry conditions for experimental work.

\section{Pulping studies}

Coir fibers were separately pulped using some variation cooking liquors concentration, based on the oven-dried pulp weight. The soda pulping methods were employed as conventional pulping processes. The pulping was carried out in a rotary digester having four bombs, each of $3 \mathrm{~L}$ capacity, with an initial digesting temperature at $40^{\circ} \mathrm{C}$. Pulping conditions for soda are presented in Table 1.

Table 1. Soda pulping conditions for coir fiber

\begin{tabular}{ll}
\hline \multicolumn{1}{c}{ Pulping Condition } & Values \\
\hline $\begin{array}{l}\text { Active alkali (as NaOH based on } \\
\text { o.d.w), \% }\end{array}$ & $10,15,20$ \\
Liquor to raw material ratio & $8: 1$ \\
Time at maximum temperature, min & $60,75,90,120$ \\
Cooking temperature, ${ }^{\circ} \mathrm{C}$ & $65,100,135$, \\
& 180 \\
Raw material weight (o.d.w), g & 200 \\
\hline
\end{tabular}

At the end of each cooking step, the pulp was then extensively washed with tap water to remove the pulp's alkalinity by controlling with a $\mathrm{pH}$ meter. Coir pulps were pressed to remove the pulp's water content and transferred to a disintegrator (Model MK IIIC, Messmer Instruments Ltd). The pulps were disintegrated in a mechanical standard disintegrator for 75,000 revolutions then stored as stock pulp. Furthermore, each pulp was evaluated for kappa number (T $236 \mathrm{~cm}-85$ ), pulp yield (T 18m53), lignin (T222 0m-88), and alpha-cellulose content (T203 cm-99).

\section{Scanning Electron Microscopy}

The structure of the obtained pulp was observed using a Phenom electron microscope. Samples for microscopy were prepared with a gold coating before the analysis using SC 7620 mini sputter coater.

\section{RESULTS AND DISCUSSION}

\section{Pulping studies}

In the early stages of this study, the time variables (60, 75, 90, and 120 mins) and solvent pulping concentration $(\mathrm{NaOH}) 10,15$, and $20 \% \mathrm{w} / \mathrm{w}$ were used as dependent variables on the soda pulping, while the initial phase of delignification $\left(135^{\circ} \mathrm{C}\right)$ and the ratio of liquid-solid (1: 8) as the controlled variables. This initial stage aims to determine the effect of reaction time and alkali charge on the value of rendement, alpha-cellulose, lignin, and kappa number.

Table 2. The chemical character of coir pulp in the initial phase of delignification $\left(135^{\circ} \mathrm{C}\right)$

\begin{tabular}{cccccc}
\hline & & \multicolumn{4}{c}{ Value } \\
\cline { 3 - 6 } Time & NaOH & Pulp & Alpha- & Lignin & Kappa \\
$\mathbf{( \% )}$ & $\begin{array}{c}\text { Yield } \\
\mathbf{( \% )}\end{array}$ & $\begin{array}{c}\text { Cellulose } \\
\mathbf{( \% )}\end{array}$ & $\mathbf{( \% )}$ & number \\
\hline 60 & & 70.66 & 48.96 & 30.38 & 162.16 \\
75 & & 69.54 & 49.76 & 28.87 & 159.44 \\
90 & 10 & 68.86 & 49.17 & 28.14 & 161.24 \\
120 & & 67.92 & 48.81 & 27.56 & 160.54 \\
\hline 60 & & 67.96 & 48.25 & 29.63 & 152.60 \\
75 & & 65.54 & 48.89 & 27.84 & 151.03 \\
90 & 15 & 64.42 & 48.95 & 26.98 & 149.83 \\
120 & & 63.90 & 48.53 & 26.07 & 149.17 \\
\hline 60 & & 65.99 & 46.78 & 27.48 & 151.03 \\
75 & & 64.62 & 47.81 & 26.25 & 150.63 \\
90 & \multirow{2}{*}{20} & 63.84 & 47.25 & 25.81 & 149.13 \\
120 & & 63.25 & 46.90 & 25.07 & 148.97 \\
\hline & & & & & \\
\hline
\end{tabular}

Table 2 shows that the recovery of pulp yield, alpha-cellulose, lignin, and kappa numbers tends to decrease with increasing reaction time and alkali charge. The residual lignin percentage in the pulp shows the amount of lignin remaining in coir fiber while simultaneously representing the lignin amount successfully excluded from initial lignin coir fiber. For the three variations of alkali charge, the delignification process is rapid in the early stages of the reaction lasting up to $90 \mathrm{~min}$, and after which, the reaction is slow.

Decreasing the pulp yield in the initial phase of delignification is due to the cleavage of nonphenolic $\beta-\mathrm{O}-4$ linkage. Increased reaction time accompanied by solvent pulping concentration will accelerate and multiply the cleavage of $\beta-O-4$ linkage by hydroxyl ions so that the lignin fragments are more soluble in the solvent pulping. Carbohydrate degradation also occurs in this phase through primary peeling reactions by cleavage of polymer at the end reactive of aldehyde group [10]. The fraction of soluble carbohydrates comes mainly from hemicellulose. The rising of solvent pulping will also cause cellulose to be degraded and dissolved in the solvent.

Significant decreases in alpha-cellulose values are shown in Table 2, especially when the solvent pulping increases from 15 to $20 \% \mathrm{w} / \mathrm{w}$. Meanwhile, the use of a long time in the early stages of soda pulping did not significantly affect alpha cellulose's value. The pulp's alpha-cellulose content increases when soda pulping is short (60-75 mins), and it is independent of the variation of pulping solvent. Within this period, the fraction of degraded 
carbohydrates is only hemicellulose, whereas cellulose is unaltered.
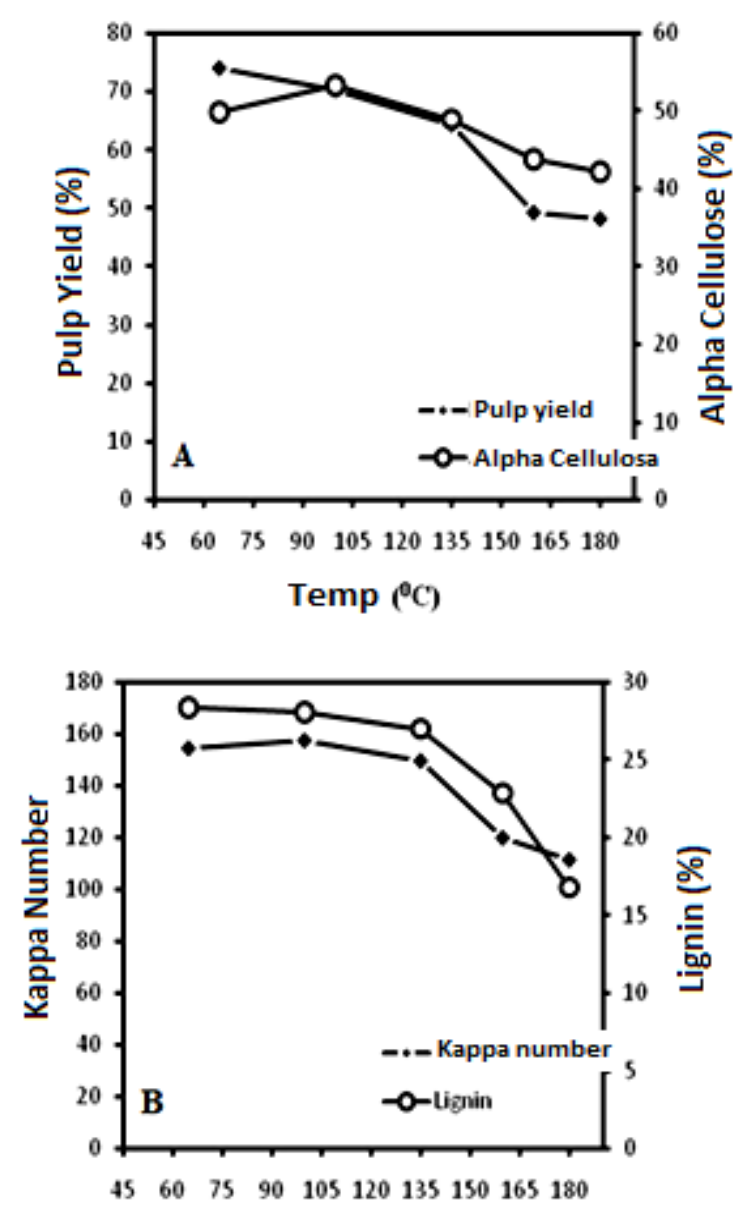

Temp $\left({ }^{\circ} \mathrm{C}\right)$

Figure 1. Effect of pulping temperature on value of pulp yield and alpha-cellulose (A), kappa and lignin numbers (B)

Soda pulping aims to eliminate lignin in fiber as much as possible, and at the same time, it focuses on the recovery of pulp yield and alpha-cellulose. Based on the above, the delignification process at $15 \% \mathrm{w} / \mathrm{w}$ of $\mathrm{NaOH}$ is used for the next step because, in this concentration, the degradation of lignin and carbohydrate degradation is not as much at $20 \% \mathrm{w} / \mathrm{w}$, which will affect the pulp yield and alpha-cellulose.

The next stage is soda pulping with temperature as the dependent variable $\left(60-180^{\circ} \mathrm{C}\right)$, and the control variables are reaction time $(90 \mathrm{~min}), \mathrm{NaOH}(15 \%$ $\mathrm{w} / \mathrm{w})$, and the ratio of liquid to solid (1: 8). Fig. 1 shows that the increase in temperature can decrease the recovery of pulp yield, alpha-cellulose, lignin, and kappa number is very significant. Delignification and carbohydrate degradation ultimately occur above a temperature of $135^{\circ} \mathrm{C}$.
The transition point between the bulk phase and the residual phase is occurring at $160^{\circ} \mathrm{C}$. Above that temperature $\left(>160^{\circ} \mathrm{C}\right)$, a significant decrease in the pulp's chemical composition is observed. The soda process for the next step is not necessary at temperatures above $160^{\circ} \mathrm{C}$. This is because, at the remaining phase, there is a side reaction that inhibits delignification.

\section{SEM Studies}
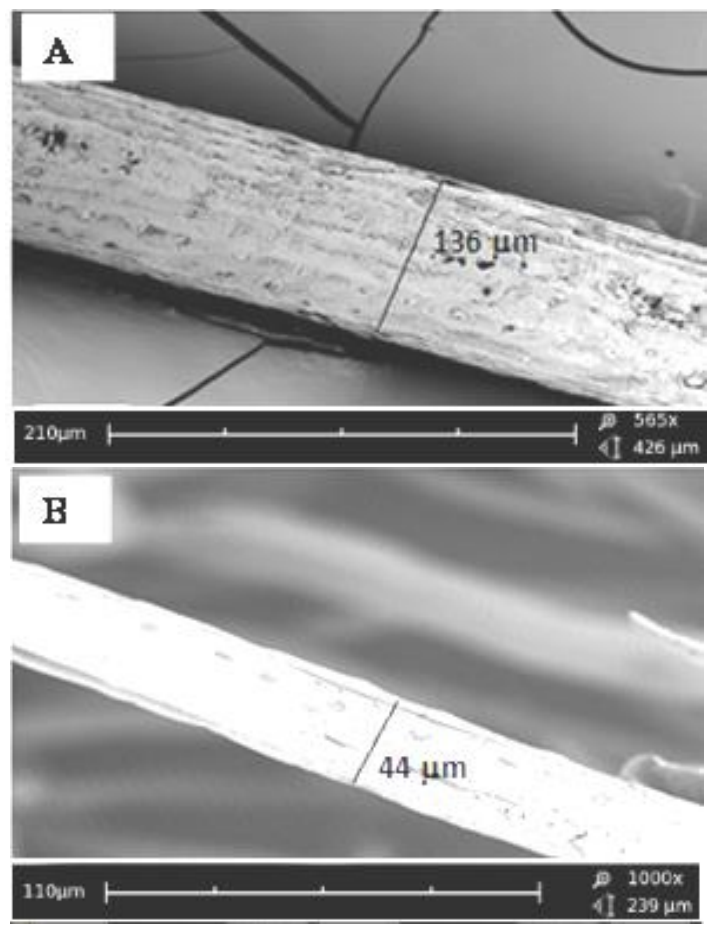

Figure 2. Morphology Surface of Coir Fiber before (A) and after (B) Soda Pulping

SEM's observation of the outer surface of coir fiber before and after the soda pulping was analyzed to determine the fiber surface's morphological changes. The SEM images of alkali-treated coir fiber (B) and untreated (A) are shown in Fig. 2. The process of soda can decrease the levels of fiber constituent components, especially cellulose, hemicellulose, and lignin. It is observed that the treatment has improved the surface roughness of the fiber as compared to the untreated fiber. This affects the reduction of fiber diameter and hole formation.

\section{CONCLUSION}

The delignification of coir fiber is optimum at $160^{\circ} \mathrm{C}, 90 \mathrm{~min}$, and $15 \% \mathrm{w} / \mathrm{w}$ of $\mathrm{NaOH}$ yielding lignin, pulp yield, and alpha-cellulose with the value of $23.52 ; 49.22$; and $44.28 \%$, consecutively. Meanwhile, morphology analysis from SEM 
indicated that coir fiber surfaces changed after the soda pulping was performed.

\section{ACKNOWLEDGEMENT}

The authors would like to thank the Department of Chemistry of Mataram University and PT. Tropica Nucifera Industry for providing relevant research facilities.

\section{REFERENCES}

[1] Sumarlan, I., Fatimah, I., \& Wijaya, K. (2020). Indonesian Modified Clay for Dye Waste Treatment. Acta Chimica Asiana, 3(1), 122-126. DOI:10.29303/aca.v3i1.11

[2] Ismillavli, N., Kamali, S. R., Hadi, S., \& Hermanto, D. (2019). Svnthesis of Biodegradable Superabsorbent Polvmers from Carboxvmethvl Cellulose/Humic Acid. Acta Chimica Asiana, 2(2), 9598. DOI: https://doi.org/10.29303/aca.v2i2.8

[3] Shanmugam, S., Kumar, T. S., \& Panneer Selvam, K. (2019). Laboratory handbook on biochemistry. PHI Learning Pvt. Ltd.

[4] Khristova, P., Bentcheva, S., and Karar, I. (1998). Soda-AQ Pulps Blends from Kenaf and Sunflower Stalks. Bioresourse Technology, 66(2), 99-103. DOI: https://doi.org/10.1016/S0960-8524(98)00058-3

[5] Cordeiro, N., Belgacem, M. N., Torres, I. C., \& Moura, J. C. V. P. (2004). Chemical Composition and Pulping of Banana Pseudo-stems. Industrial Crops $\mathcal{E}$ Products, 19(2), 147-154. DOI: https://doi.org/10.1016/j.indcrop.2003.09.001

[6] Singh, S., Dutt, D. and Tyagi, C.H. (2011). Complete Characterization of Wheat Straw (Triticum aestivum PBW-343 L.Emend. Fiori and Paol.) - A Renewable Source of Fibres for Pulping and Papermaking. BioResources, 6(1), 154-177.

[7] Khristova, P., Kordschia, O., Patt, R., Khider, T., \& Karrar, I. (2002). Alkaline Pulping with Additives of Kenaf from Sudan. Industrial Crops \& Products, 15(3), 229-235. DOI: https://doi.org/10.1016/S09266690(01)00118-2

[8] Rodriguez, A., Morala, A., Serrano, L., Labidib, J., and Jimenez, L. (2008). Rice Straw Pulp Obtained by Using Various Methods, Biouresourse Technology, 99(8), 2881-2886. DOI: 10.1016/j.biortech.2007.06.003
[9] Eddi, M. \& Shinagawa, S. (1982). Komposisi Kimia Sabut Kelapa dan Kemungkinan Pemanfaatannya untuk Pulp. Berita Selulosa, 18(4), 101-104.

[10] Joedodibroto, R. (1990). Beberapa Prospek dan Masalah dalam Pemanfaatan Sabut Kelapa untuk Pulp Kertas. Berita Selulosa, 26(1), 3-8.

[11] Agopyan, V., Savastano Jr, H., John, V. M., \& Cincotto, M. A. (2005). Developments on Vegetable Fibre-Cement Based Materials in San Paulo, Brazil: An Overview. Cement and Concrete

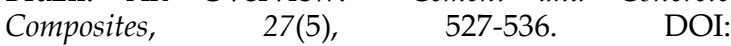
10.1016/j.cemconcomp.2004.09.004

[12] Asasutjarit, C., Hirunlabh, J., Khedari, J., Charoenvai, S., Zeghmati, B. \& Shin, U. C. (2007). Development of Coconut Coir-based Lightweight Cement Board. Construction and Building Materials, 21(2), 277-288. DOI: 10.1016/j.conbuildmat.2005.08.028

[13] Abdul Khalil, H. P. S., Ireana-Yusra, A. F., Bhat, A. H. and Jawaid, M. (2009). Cell Wall Ultrastructure, Anatomy, Lignin Distribution and Chemical Composition of Malaysian Cultivated Kenaf Fiber. Industrial Crops \& Products, 31(1), 113-121. DOI: https://doi.org/10.1016/j.indcrop.2009.09.008

[14] Saleh, A., Pakpahan, M. M. D., \& Angelina, N. (2009). Pengaruh Konsentrasi Pelarut, Temperatur dan Waktu Pemasakan pada Pembuatan Pulp dari Sabut Kelapa Muda. Jurnal Teknik Kimia, 17(3), 3544. 